\author{
Michał Łuczyński \\ Uniwersytet Jagielloński, Kraków \\ michal.luczynski@uj.edu.pl
}

\title{
GDZIE WALCZYŁ I JAK MIAŁ NA IMIĘ BRAT MIESZKA I?
}

Słowa klucze: onomastyka, antroponimia, toponimia, nazwa własna, dynastia Piastów Keywords: onomastics, anthroponymy, toponymy, proper name, the Piast dynasty

W jednym z opracowań dla maturzystów poświęconym historii Polski czytamy:

W roku 972 na terytorium Mieszka najechał margrabia Hodon, zarządzający Marchią Łużycką; celem tej wyprawy było powstrzymanie ekspansji państwa polskiego nad Bałtykiem. Do bitwy doszło w pobliżu grodu Cedynia na Pomorzu Zachodnim; oddziały Mieszka i jego brata Czcibora zadały najeźdźcom dotkliwą klęskę [...] (Sochacki 2007: 113).

Podobnie na etapie kształcenia uniwersyteckiego obowiązuje interpretacja głosząca, iż Mieszko starł się z Hodonem pod Cedynią, por. fragment jednego z podręczników:

Margrabia Marchii Wschodniej Hodo najechał na ziemie polskie i został pobity pod Cedynią u ujścia Warty do Odry [...]. W dzień św. Jana Chrzciciela starli się z Mieszkiem, odnieśli zrazu zwycięstwo, lecz potem w miejscowości zwanej Cedynia brat jego [...] Czcibór zadał im klęskę (Bogucka 1999: 22-23)².

1 Podobnie: Czubiński, Topolski 1989: 34; Topolski 1992: 45; Strzelczyk 1992: 51; Dybkowska, Żaryn, Żaryn 2002: 4; Barański 2005: 50; Rymar 2005: 40; Samsonowicz et al. 2007: 33; Urbańczyk 2012: $137 \mathrm{i}$ in. 
W polskiej historiografii przyjęło się uważać, iż miejscem bitwy, do której doszło między siłami margrabiego Marchii Wschodniej a wojskami państwa gnieźnieńskiego, była niewielka przełęcz na terenie Cedyńskiego Parku Narodowego nieopodal grodu Cedynia, a z odsieczą wojskom Mieszka przybył jego brat Czcibor, względnie Czcibór. Wersja taka zawiera niewątpliwie dwa anachronizmy. Ani bowiem brat księcia nie miał na imię Czcibor // Czcibór, ani słowiańska nazwa miejscowości będącej areną wydarzeń opisanych w kronice Thietmara nie mogła brzmieć Cedynia. W świetle starszych i nowszych badań historycznych oraz językoznawczych, także przedstawionej niżej mikrofilologicznej analizy źródła historycznego, nie ulega kwestii, iż jest to mit historyczny stworzony na potrzeby polityki władz Polski Ludowej, mający uzasadniać pretensje do Ziem Odzyskanych w sporze o rewindykację terenów nad Odrą ${ }^{2}$.

Jan M. Piskorski (2002: 77) stwierdził, iż walczył tam nie Czcibor, lecz Ździbor, jako że imię to jego zdaniem bardziej odpowiada regułom transkrypcji łacińskiego zapisu Cidebur. Z kolei Krzysztof T. Witczak (1992) dekadę wcześniej dowodził, że imię słowiańskie Ździbor nie mogłoby dać łacińskiej transkrypcji Cidebur, lecz i jego lekcja: Zdziebor, budzi wątpliwości, podobnie jak wiele innych. Natomiast identyfikację Cidini = Cedynia odrzucono już dawno, gdyż przeczyły jej dane językowe i argumenty językoznawcze. Należy więc zgodzić się z M. Piskorskim, iż miejsce potyczki „polska powojenna historiografia utożsamiła niemal na dobre z dzisiejszą Cedynią koło Chojny, mimo iż jest to tylko jedna z hipotez roboczych" (Piskorski 2002: 77). Zmitologizowany obraz bitwy rozegranej 24 czerwca 972 r., choć niewątpliwie o dużym znaczeniu we wczesnej historii państwa, został znacznie zafałszowany przez część historyków i do dziś funkcjonuje raczej jako relikt propagandy sprzed kilku dziesiątków lat niż rezultat rzetelnych badań naukowych.

W kronice Thietmara, który (obok Brunona z Kwerfurtu) jako jedyny przekazał informację o tym starciu, czytamy:

Interea Hodo, venerabilis marchio, Miseconem imperatori fidelem tributumque usque in Vurta fluvium solventem exercitu petivit collecto. Ad cuius auxilium pater meus comes Sigifridus, tunc iuvenis necdumque coniugali sociatus amori, venit solum cum suis et in die sancti lohannis baptistae adversus eum pugnantes primoque vincentes a fratre eiusdem Cideburo, exceptis tantum comitibus prefatis, omnes optimi milites interfecti oppecierunt in loco, qui vocatur Cidini (MPH: 248 - wyróżn. M.Ł.).

Tymczasem dostojny margrabia Hodo, zebrawszy wojsko, napadł z nim na Mieszka, który był wierny cesarzowi i płacił trybut aż po rzekę Wartę. Na pomoc margrabiemu pospieszył wraz ze swoimi [zbrojnymi - M.Ł.] tylko mój ojciec, graf Zygfryd, podówczas młodzieniec i jeszcze nieżonaty. Kiedy w dzień św. Jana Chrzciciela starli się

2 Dotychczasowe poglądy na temat bitwy cedyńskiej wyczerpująco referuje Paweł Migdalski (2004, 2013). 
z Mieszkiem, odnieśli zrazu zwycięstwo, lecz potem w miejscowości zwanej Cidini brat jego Cidebur zadał im klęskę, kładąc trupem wszystkich najlepszych rycerzy z wyjątkiem wspomnianych grafów (Thietmar: 88).

Znamy właściwie tylko nazwy substytucyjne: śr.łac. Cidebur i Cidini. Słowiańskie imię brata Mieszka I próbowano dotychczas rekonstruować m.in. jako Czcibor, Ścibor, Zdziebor; autorem ostatniej lekcji jest K.T. Witczak, który poświęcił temu problemowi osobny artykuł (1992), uzasadnił też wystarczająco nieprawidłowość pozostałych prób odczytania zapisu Thietmara. Natomiast nazwę miejscowości czytano dotychczas m.in. jako Sitno, Cydno, Žydno (Brückner 1935: 24); Szczytno, Sitno, Žytno (Rospond 1947: 298-299), a także Sidzina (Lehr-Spławiński 1958/1961: 86-88). Tadeusz Lehr-Spławiński w lekcji Sitno za zasadne uznaje tylko czytanie początkowego niem. $c$ - jako odpowiednika słow. nagłosowego $s^{-}$, na postawie znakowania (c) $=/ \mathrm{s} / \mathrm{w}$ łacinie autorów niemieckich przełomu X/XI w. (Lehr-Spławiński 1958/1961: 86). Przypuszcza dalej, iż niem. - $d$ - oddaje słow. -d’-, co służy mu za podstawę lekcji *Sid’ina, którą porównuje następnie z ojkonimem Sidzina zanotowanym dwukrotnie na terenie Małopolski (ibid.: 87). Jednak i z tą interpretacją nie można się zgodzić. Otóż T. Lehr-Spławiński pisze, iż zakładana przez lekcję Sitno oscylacja $t \leftrightarrow d$,nie zachodzi zasadniczo w pisowni Thietmara, raczej więc pozostać należy przy -d-” (ibid.: 86). Jak jednak zauważa Stanisław Rospond:

Biskup merseburski Thietmar [...] używa w odniesieniu do materiału śląskiego i w ogóle słowiańskiego pisowni zdradzającej silne nacechowanie graficzno-fonetyczne staroniemieckie, ściślej turyńsko-saksońskie. Zarówno w zakresie wokalizmu, jak i konsonantyzmu występują tu właściwości typowe dla niemieckiego [...] (Rospond 1957: 8).

Można zaliczyć do nich wahanie w pisowni $t: d$, co pozwala zakwestionować odczyt Lehra-Spławińskiego. Przemawiają przeciwko niemu również śr.łac. zapisy Abodriti, Abdriti, Apotriti 'Obodrzycy', a także Zutibure, Zudibure 'Święty Bór', w których $t$ alternuje z $d$ (przykłady za: Rospond 1955: 182; 1969: 166). Można uznać zatem, iż argument powołujący się na pisownię (d) = /d'/ należy odrzucić, a zapisy kroniki Thietmara rozpatrzyć ponownie na tle ortografii zabytków staroniemieckich.

Wydaje się, iż aby dokonać prawidłowej delatynizacji obydwu zapisów, powinno się przede wszystkim uwzględnić grafię łacińskich zabytków najbliższych praktyce pisarskiej Thietmara, który swą kronikę napisał ok. 1017 r. Są nimi niewątpliwie roczniki i źródła dyplomatyczne z terenu Saksonii i Austrii, pisane w IX-X w. łaciną wykazującą wpływ języka dolnoniemieckiego.

Zacznijmy od próby ustalenia lekcji śr.łac. Cidebur. Otóż jest to jedna z kilku transkrypcji z grupą -ide-, które można odnaleźć w tekstach należących do zakreślonego wcześniej areału. Należy do nich na przykład zapis imienia słow. Zidebit (975; FRA: 40). Jest to wariant graficzny nazw substytucyjnych Sitiuit, Situuit ( ${ }^{\star Z}$ Zitivitz), 
$\mathrm{z}$ typowo niemiecką alternacją $z: s$ i grafią $(\mathrm{d})=/ \mathrm{t} /$ oraz $(\mathrm{b})=/ \mathrm{v} / 3$. Zapisy te dowodzą, że wartość spółgłoskowa /t/ grafemu (d) nie ulega wątpliwości. Transkrypcja łacińska -ide- oddaje grupę psł. *-it’i-, pol. - yci-; we współczesnej polszczyźnie imię brzmiałoby zapewne Życiwit. W przypadku nazwy substytucyjnej Cidebur grafem (d), jak wspomniano, można również odczytywać jako słow. /t'\% Uwzględniwszy znakowanie w łacinie dolnoniemieckiej /'e/ jako (i) oraz nagłosowego /s/ jako (c), otrzymamy lekcję omawianego zapisu w postaci Sieciebor ( ${ }^{\star}$ Sĕt’eborz).

W kwestii delatynizacji zapisu Cidini można analogicznie przyjąć, iż oddaje on formę słow. z nagłosowym (s), w czym należy zgodzić się z T. Lehrem-Spławińskim, natomiast $\mathrm{w}$ kwestii $(\mathrm{d})=/ \mathrm{d} /$ konieczne wydaje się założenie substytucji $(\mathrm{d})=/ \mathrm{t} /$. Grafem (d) może być istotnie interpretowany dwojako, najbliższej analogii w tej kwestii dostarczają jednak zapisy z terenu języka dolnoniemieckiego, które przemawiają za przyjęciem znakowania przez (d) słow. /t/. Pozwalałoby to na wstępne odczytanie nazwy jako Sitini, wymaga ono jednak dalszych uściśleń interpretacyjnych i poprawek. Można $\mathrm{z}$ dużym prawdopodobieństwem założyć, że drugie (i) $\mathrm{w}$ nazwie $=/ \mathrm{b} /$ (jer należący do przyrostka ${ }^{\star}$ Sit- $\left.\_n-i\right)$, natomiast wtórne - $i$ (ostatnie w zapisie) oddawało najpewniej słow. samogłoskę o lub $a$, co pozwala ostatecznie czytać zapis Cidini nie jako Cedynia, lecz jako Sitno lub Sitna $\left({ }^{\star}\right.$ Sitzno // ${ }^{\star}$ Sitzna).

Delatynizacja zapisów w postaci Sieciebor i Sitno a. Sitna ma tę przewagę nad innymi interpretacjami, iż opiera się na bliskich chronologicznie źródłach pochodzących z bezpośredniego kręgu językowego kronikarza i wymaga minimalnej liczby dodatkowych założeń. $W$ tym sensie procedura ta wydaje się bardziej ścisła i nie powoduje konieczności dopuszczania dwojakiej interpretacji zapisów, które na szerokim materiale porównawczym oddającym zróżnicowane chronologicznie i regionalnie zwyczaje substytucyjne rzeczywiście mogą być odczytywane rozmaicie. Za właściwy należy więc uznać odczyt Sitno Brücknera-Rosponda, natomiast rekonstrukcja antroponimu Sieciebor nie została dotychczas sformułowana i jest niewątpliwym novum w literaturze naukowej.

Nazwy substytucyjne bliskie tej formie odnajdujemy na Pomorzu Zachodnim: śr.łac. Zitcebur /1302/, Zytzebor /1316/, Zitzebur /1358/, Tzitsebur /1326/; przez niektórych badaczy odczytywane są one jako stpol. Siecibor lub Cicebor (np. Schlimpert 1964: 31), mogą być również interpretowane jako próby zapisu imienia ${ }^{\star} S e ̆ t ’ e b o r z$, czyli Sieciebor (łac. Sicebor /1258/) 4 . Jest to compositum z pierwszym członem pochodzącym od psł. *sětiti 'rozumieć, przypominać sobie, domyślać się, czuć, spostrzegać' (SMot: 265) oraz drugim pochodzącym od psł. *bor- 'zmagać się, mocować się, pasować się, walczyć' (ibid.: 16). Znaczenie strukturalne nazwy osobowej złożonej ${ }^{\star}$ Set'eborz to 'niech pamięta o walce', 'pamiętaj o walce' itp., podobnie jak Siecie-sław 'niech pamięta o sławie'. Byłoby to zatem imię życzące. O tym, iż występowało

3 Franz Miklosich (1860: 63) nazwę Zidebit zaliczał do imion derywowanych od podstawy ${ }^{\star} z ̌ i v z$.

4 Na podstawie śląskiej toponimii imię takie rekonstruuje S. Rospond (1964: 82; 1970: 78). 
ono dość często w staropolskim imiennictwie osobowym, świadczą (oprócz licznych toponimów patronimicznych i deantroponimicznych) formy typu Cyseborio 'Sieciebor' (ibid.: 17), bliskie transkrypcji zanotowanej u Thietmara (tzn. stosujące substytucję $(\mathrm{c})=/ \mathrm{s} /$ oraz $(\mathrm{i}),(\mathrm{y})=/ \mathrm{e} /)$. Można więc zasadnie powiedzieć, iż w świetle analizy mikrofilologicznej najbardziej prawdopodobną lekcją zapisu Cideburo (Cidebur w mianowniku) jest Sieciebor, imię spotykane zarówno na Pomorzu, jak i na Śląsku, czego dowodzą odpowiednie, zacytowane wyżej formacje antroponimiczne.

Zasadniczych trudności nie sprawia wskazanie możliwej lokalizacji miejsca, w którym odbyła się bitwa. Mimo iż Henryk Borek (1968: 211; 1983: 180) z terenów zachodniosłowiańskich wymienia 39 nazw miejscowych utworzonych od podstawy *sits 'sitowie, trzciny', na podstawie informacji Thietmara interesującą nas nazwę miejscową Sitno // Sitna można z dość dużym stopniem prawdopodobieństwa lokalizować na północ od ujścia Warty do Odry na Pomorzu Zachodnim, a więc w rejonie lucicko-polańsko-niemieckiego pogranicza, które wskazuje się czasem jako arenę bitwy. Nadwarciańska hydronimia obfituje bowiem w formacje typu Siecienica, Sitna, Sitno (Rieger, Wolnicz-Pawłowska 1975: 143-144), które dadzą się wyprowadzić od rdzenia ${ }^{*}$ sit-. Na podstawie dotychczasowych rozważań „locus, qui vocatur Cidini” można zasadnie identyfikować nie z Cedynią, lecz na przykład z okolicami jezior Sitno, Siecina lub rzeki Sitna (dawniej Sitnica) na terenie Drawieńskiego Parku Narodowego (pow. wałecki, gm. Tuczno), a także z jakąkolwiek wsią o podobnej nazwie istniejącą we wczesnym średniowieczu na Pomorzu Zachodnim. Lokalizacja ta wydaje się odpowiadać opisowi Thietmara, który niedwuznacznie wskazuje na dorzecze Warty znajdujące się w niedalekiej odległości od ujścia Odry. Sitno, Siecina oraz Sitna znajdują się w dorzeczu dolnej Warty i spełniają kryteria geograficzne odpowiadające Cidini w stopniu daleko wyższym niż nadodrzańska Cedynia. Nagromadzenie nazw miejscowych od apelatywu ${ }^{*}$ sit na obszarze środkowego Nadodrza wspiera hipotezę o występowaniu we wczesnym średniowieczu toponimu Sitno // Sitna wzmiankowanego przez Thietmara. Ponadto opis kronikarski jednoznacznie wskazuje na jego położenie w zachodniej części Pomorza, nie zaś na Połabiu, ponieważ kronikarz nie określiłby wówczas wyprawy Hodona jako ataku na terytorium Mieszka. Niewykluczone zatem, iż Cidini należy poszukiwać w rejonie lewobrzeżnej Drawy i jej dopływów.

Lokalizacja taka usuwa trudności związane z odtworzeniem trasy wyprawy wojennej margrabiego Łużyc. Niezależnie od tego, czy założymy przekroczenie przez Hodona i Zygfryda granicy w rejonie Warty koło dzisiejszego Gorzowa Wielkopolskiego czy dolnej Odry (tj. wkroczenie na ziemie Mieszka od południowego zachodu lub od zachodu) $)^{5}$, kryterium geograficzne wspiera proponowaną wyżej identyfikację. Jak wynika z opisu Thietmara, po pierwszym starciu Sasi mogli odczytać

5 Jak przypuszczają historycy, wojsko Sasów mogło wkroczyć na ziemię Piastów z terytorium zarówno Łużyczan, jak i Wieletów (Labuda 1987: 114-119). 
pozorowany odwrót księcia jako ucieczkę i zachętę do wszczęcia pościgu. Skwapliwie z tej szansy skorzystali. Nie ulega wątpliwości, że siły Sieciebora postawione były wówczas w stan gotowości i zmobilizowane, co, jak domyślają się historycy, związane było z koncentracją wojskową wokół Wolina, który książę chciał sobie podporządkować siłą. Hodo i jego jedyny sojusznik trafili więc na dużą koncentrację oddziałów, które nadciągnęły wkrótce po wycofaniu się Mieszka w rejon Cidini. Należy zauważyć, iż Cedynia jako lokalizacja pola bitwy nie spełnia warunków geograficznych: wkroczenie Mieszka z oddziałami na teren Marchii Północnej zostałoby bowiem odebrane jako wypowiedzenie wojny Cesarzowi, tylko w tym wypadku zrozumiały byłby odwrót przez dolinę u stóp grodu Cedynia. Ucieczka do Cedyni z Pomorza Zachodniego również nie wydaje się prawdopodobna, gdyż oznaczałaby niekorzystną sytuację strategiczną do rozegrania bitwy dla wojsk Mieszka. Jedynie kierunek północny (lub północno-zachodni) względem ujścia Warty do Odry wydaje się spełniać warunki lokalizacji Cidini. Niejasności związane z trasą przemarszu Hodona, który do drugiej bitwy natrzeć miał od strony północno-zachodniej ku południowemu wschodowi (Labuda 1987: 120), w zależności od hipotetycznego punktu wyjścia przed wkroczeniem na ziemie Piastów, można wyjaśnić kierunkiem wschodnim pościgu Sasów (w przypadku hipotezy „odrzańskiej”). Jakkolwiek odtwarzać hipotetyczny przebieg bitwy, nie ulega wątpliwości, iż hipotezy historyków wojskowości - tradycyjnie uwzględniające Cedynię jako teren rozegrania bitwy należy poddać daleko idącej rewizji.

Wydaje się, iż dotychczasowe rozważania historyków, prowadzone bez uprzedniej właściwej delatynizacji nazwy miejscowej, skazane były na niepowodzenie przez obracanie się w kręgu niesprawdzalnych hipotez, miały więc charakter spekulatywny. Identyfikacja Cidini $=$ Sitno albo Sitna $\left({ }^{\star}\right.$ Sitzno // ${ }^{\star}$ Sitrna) znacząco zawęża obszar możliwych lokalizacji historycznej bitwy do zachodniej części Pojezierza Zachodniopomorskiego, przez co dociekania na temat „wiktorii cydyńskiej” zyskują jak się wydaje - bardziej trwały niż dotąd fundament dalszych badań. Natomiast transkrypcja śr.łac. Cidebur jako Sieciebor ( ${ }^{\star}$ Sĕt’eborz) to nowa próba odczytania imienia jednego z braci Mieszka I (który odegrał ważną rolę w historii wczesnego państwa polskiego), uzupełniająca wiedzę o antroponimii wczesnopiastowskiej.

Podsumowując, interesujący nas fragment kroniki Thietmara należy tłumaczyć następująco:

Kiedy w dzień św. Jana Chrzciciela starli się z Mieszkiem, odnieśli zrazu zwycięstwo, lecz potem w miejscowości zwanej Sitno brat jego Sieciebor zadał im klęskę [...].

Tłumaczenie tekstu źródłowego w powyższej postaci może być wykorzystane $\mathrm{z}$ niewątpliwym pożytkiem dla nauk historycznych. $Z$ tego punktu widzenia istotny wydaje się przede wszystkim fakt, iż przyjęcie Sitna nad Drawą (dopływem Noteci) jako miejsca starcia znacząco zmienia obraz bitwy, która rozegrała się 24 czerwca $972 \mathrm{r}$. 


\section{Skróty}

łac. - łaciński, niem. - niemiecki, pol. - polski, psł. - prasłowiański, słow. - słowiański, stpol. - staropolski, śr.łac. - średniołaciński

\section{Źródła}

FRA: Fontes rerum Austriacarum, II: Diplomataria et acta, t. 31, red. J. Zahn, Wien 1870.

Thietmar: Kronika Thietmara, tłum. i red. M.Z. Jedlicki, Poznań 1953.

MPH: Monumenta Poloniae historica - Pomniki dziejowe Polski, t. I, wyd. A. Bielowski, Lwów 1864.

\section{Literatura}

Barański M., 2005, Dynastia Piastów w Polsce, Warszawa.

Bogucka M., 1999, Historia Polski do 1864 roku, Wrocław - Warszawa - Kraków.

BoreK H., 1968, Zachodniosłowiańskie nazwy toponimiczne $z$ formantem *-ъn-, Wrocław.

Borek H., (red.), 1983, Hydronimia Odry. Wykaz nazw w układzie hydrograficznym, Opole. BRÜCKNER A., 1935, O nazwach miejscowych, „Rozprawy Wydziału Filologicznego PAU” t. LXIV, nr 2, Kraków.

Czubiński A., Topolski J., 1989, Historia Polski, Warszawa.

Dyвкоwska A., ŻAryn J., ŻAryn M., 2002, Polskie dzieje od czasów najdawniejszych do wspótczesności, wyd. 7, Warszawa.

LABUda G., 1987, Studia nad początkami państwa polskiego, t. 1, wyd. 2, Poznań.

Lehr-Sp£awiński T., 1958/1961, Cidini - Sidzina, [w:] idem, Od piętnastu wieków. Szkice z pradziejów i dziejów kultury polskiej, Warszawa, s. 86-88.

Migdalski P., 2004, Znaczenie i lokalizacja bitwy pod Cidini w świetle historiografii, [w:] J.M. Piskorski (red.), Civitas Schinesghe. Mieszko I i początki państwa polskiego, Poznań Gniezno, s. 159-169.

Migdalski P., 2013, Bitwa pod Cidini $w$ historiografii, [w:] idem (red.), Cedynia i okolice poprzez wieki, Chojna - Szczecin, s. 37-64.

Miklosich F., 1860, Die Bildung der slavischen Personennamen, Wien.

Piskorski J.M., 2002, Pomorze plemienne. Historia - Archeologia - Językoznawstwo, Poznań - Szczecin.

Rieger J., Wolnicz-PawŁowska E., 1975, Nazwy rzeczne w dorzeczu Warty, „Prace Onomastyczne PAN", nr 24, Wrocław.

Rospond S., 1947, Pierwotna nazwa Szczecina a pótnocno-zachodnia granica Polski Piastowskiej, „Slavia Occidentalis” t. 18, s. 291-304.

Rospond S., 1955, Uwagi polemiczne o Mieszku, Masławie $i$ Dąbrówce, „Onomastica” I, s. $168-185$. 
Rospond S., 1957, Polsko-niemieckie substytucje graficzne i fonetyczne w najdawniejszych dyplomach i tekstach ślaskich, „Zeszyty Naukowe Uniwersytetu Wrocławskiego”, seria A: "Językoznawstwo" nr 5, s. 3-37.

Rospond S., 1964, Patronimiczne nazwy miejscowe na Śląsku, „Prace Wrocławskiego Towarzystwa Naukowego", seria A, nr 89, Wrocław.

Rospond S., 1969, Alemure w „Dagome iudex”, [w:] W. Krauss, Z. Stieber, J. Belič, V.I. Borkovskij (red.), Slawisch-deutsche Wechselbeziehungen in Sprache, Literatur und Kultur, „Veröffentlichungen des Instituts für Slavistik der Deutschen Akademie der Wissenschaften zu Berlin" 44, Berlin, s. 163-168.

Rospond S., 1970, Słownik etymologiczny nazw geograficznych Śląska, t. 1, Warszawa Wrocław.

RYMAR E., 2005, Rodowód ksiażąt pomorskich, Szczecin.

Samsonowicz H., Wyczański A., Tazbir J., Staszewski J., Kizwalter T., Na€ęcz T., Paczkowski A., Chwalba A., 2007, Historia Polski, t. 1, Warszawa.

SChlimpert G., 1964, Slawische Personennamen in mittelalterlichen Quellen Deutschlands, Berlin.

SМот: Słownik etymologiczno-motywacyjny staropolskich nazw osobowych, cz. 1: Odapelatywne nazwy osobowe, oprac. A. Cieślikowa, Kraków 2000.

Sochaскi W., 2007, Historia dla maturzystów. Repetytorium, Bydgoszcz - Warszawa.

Strzelczy J., 1992, Mieszko Pierwszy, Poznań.

Topolski J., 1992, Historia Polski, Warszawa - Kraków.

Urbańczyk P., 2012, Mieszko Pierwszy Tajemniczy, „Monografie Fundacji na Rzecz Nauki Polskiej”, Toruń.

WitczaK K.T., 1992, Z antroponimii piastowskiej: Zdziebor (nie Czcibor), brat Mieszka I, „Onomastica” XXXVII, s. 123-132.

\section{Where did the brother of Mieszko I fight and what was his name? Summary}

The paper is an attempt to decipher the name of the brother of Mieszko I and place name where battle with german duke Hodon took place in 972, mentioned in Thietmar of Merseburg's chronicle. They are only known from a single MLat. inscription as Cidebur, and from its Latinized form as Cidini . In an author's view they should be delatinized as Siecebor and Sitno (Sitna). Based on a substition and transcription analysis, the author formulates a hypothesis concerning the location and progress of the battle. 